\title{
THE FEATURES OF TEACHER TRAINING FOR MEDIA EDUCATION OF STUDENTS IN THE DEVELOPED ENGLISH-SPEAKING COUNTRIES
}

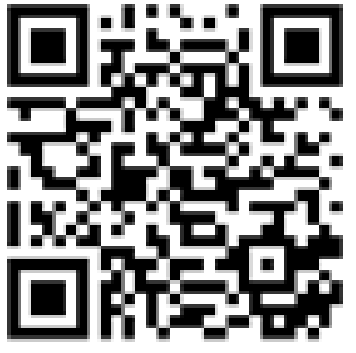

To cite this article:

\author{
Nataliia Prykhodkina, Dr. Sc., Ass. Prof. \\ Professor, Department of Pedagogy, \\ Management and Administration, \\ State Educational Institution of Higher Education \\ "University of Education Management", \\ National Academy of Educational Sciences of Ukraine \\ Kyiv, Ukraine \\ prykhodkina2019@gmail.com \\ https://orcid.org/0000-0002-6211-5546
}

\begin{abstract}
Prykhodkina, N. (2021). The features of teacher training for media education of students in the developed English-speaking countries. Education: Modern Discourses, (4), 103-115.

https://doi.org/10.37472/2617-3107-2021-4-10
\end{abstract}

Abstract. Media literacy deserves a special place in teacher education, as it stimulates critical thinking, including a variety of reading, writing and speaking skills, the use of computer technology and the decoding of various types of information. In the article, the author analyzes the features of teacher training for media education of students in developed English-speaking countries. Media literacy, introduced into training programs, can be very useful and effective. Preparation for the development of media literacy of teachers can be carried out in the process of advanced training, educational psychology courses, basic training courses and teaching practice. Media literacy contributes to critical thinking, focusing on social issues, understanding the branches of knowledge and children, and shaping teacher professionalism. Media literacy offers prospective teachers new opportunities to succeed and improve school performance. The Canadian, British, Australian, American colleges and universities train teachers in media education. They are acquainted with the media education theory and practice, modern technologies of media education on the system of «key concepts», possibilities of using digital technologies in the process of media education of students. The National Media Education Associations offer vocational courses and media workshops for teachers. One of the most popular ways to improve the qualification and self-education of teachers is MOOC (Futurelearn, Coursera, EdX).

Keywords: association; college; English-speaking countries; media; media literacy; teachers; university.

\section{INTRODUCTION, PROBLEM STATEMENT}

Innovation in media education development strategy is an essential resource and the main form of relevant education activity. The large amount of information available enables a person to narrow the space-time boundaries as much as possible. But at the same time, information redundancy requires both teachers and students to be able to critically comprehend 
new knowledge (information material), navigate the flow of media products, understand and decipher the media. The active introduction of new technologies in the education makes it possible to use the accumulated pedagogical experience and to adapt it to new conditions. N. Avsheniuk analysing trends in the professional growth of teachers in developed Englishspeaking countries in the context of globalization, identifies that the increasing diversity in the professional growth of teachers through the development of ICT is one of the main trends (Avsheniuk, 2016).

Media education deserves a special place in the teachers' training as it stimulates critical thinking in the age of information and digital society. It offers new ways of engaging students in learning, building relationships between students, school and personal life, teachers, etc. Teachers should be able to model the media literacy of their students.

Media literacy is the way in which literacy can be introduced into the education process in schools of the English-speaking coutries at all levels. It is an incentive for further training courses for teachers, courses in education psychology, basic training courses and pedagogical practice. Media literacy promotes critical thinking, a focus on social issues, an understanding of areas of knowledge and children, and a teacher's professionalism. It allows teachers to make a statement.

\section{LITERATURE REVIEW}

According to J. Davies "media literacy includes what will make teachers the best" (Davies, 1996).

D. Considine highlights the following advantages of media literacy for future teachers: 1) media literacy is a interdisciplinary field that is easily integrated into key elements of the curriculum; 2) media literacy is a problem-oriented area which is rich in reflective learning and critical thinking; 3) media literacy contains practical learning and corresponds to the study of learning styles; 4) media literacy works well in teams and groups, facilitating collaborative learning; 5) media literacy is successful when it comes to attracting students to improve the "drop-out rate"; 6) media literacy is compatible with SCANS (State Commission on Acquiring the Necessary Skills) and promotes employment; 7) media literacy links the classroom curriculum with the curriculum for a wide range of education users (Considine, 1995).

The training of teachers in the use of media in pedagogical activities and the integration of media education in school disciplines is an important aspect of their vocational training based on special knowledge and skills; the content of which is related to the basic concepts of media education, media personality, media competence of the teacher, forms and methods of media education) and the indicator of the teacher's readiness to work with mass media (Yakymchuk, 2019).

An important stage in the solution of the problem of teachers' training for media education of students at the international level is the development and publication of UNESCO "Education Programme on Media and Information Literacy for Educators" (2011). O. Lokshyna notes that the "teachers' professional growth is positioned by UNESCO as a long-term process encompassing regular opportunities and experiences aimed at promoting career growth" (Lokshyna, 2020). UNESCO has succeeded in drawing the attention of the international community to the concept of media and information literacy. The program trains teachers to work with a complex set of different media channels and resources: libraries, archives and the Internet. It is an important resource of competence in the process of improving the quality of teaching of traditional disciplines.

The Program can be used to promote media and information literacy within any subject and be part of both a separate and an integrated program. In general the media and information 
literacy curriculum is created to help teachers to learn and understand the key concepts of media and information literacy; related theoretical frameworks, methodologies and conceptual tools; strategies for the analysis of various media and information texts, determining who creates them, how and for what purpose; bases for the analysis of messages and their impact on the audience; strategies for the retrieval, reception and storage of information; means of creation of media and information texts; approaches to curriculum planning; research and problemsolving processes; strategies for introducing meta-cognition, problem-oriented and researchbased learning; and possible analysis and assessment strategies tailored to the students' needs.

In addition the curriculum examines the opportunities, rights and responsibilities of citizens in dealing with the media; international standards (Common Declaration of Human Rights, constitutional guarantees of freedom of expression, as well as their limitations, such as the prohibition of incitement to hatred and defamation, privacy) in the context of certain countries; ethical responsibility of the media (pluralism and diversity as a well-established norm, strict verification of facts as the basis of journalism, the role of ethical principles in advertising and language media) (Digital World, 2008).

The teacher must acquire a certain set of skills that have helped him to organize the process of developing students' media literacy. UNESCO identifies several basic media competencies of the teachers.

Understanding the meaning of media and information. The teacher knows the ethics of creating news and other media information, understands the functions of media and other information services.

Understanding media content and its usage. Within this competence the teacher can demonstrate knowledge and understanding of the various ways in which media is used in his personal and professional life, interpret media texts and establish links between them, context and values reproduced in the media, use established approaches to analyse stereotypes in the media, etc.

Effective and prompt access to information. The teacher determines the type of information needed for a specific task, can access this information efficiently and quickly, defines keywords and related terms for access to information, defines different formats and types of information sources.

Critical evaluation of information and information sources. The teacher critically evaluates the information and its sources, uses its contents to analyse ideas and solve problems; evaluates the credibility, reliability, accuracy, timeliness and impartiality of the source; recognizes bias and manipulation, the social and cultural contexts in which information is created, and understands the impact of those contexts on the interpretation of information.

Usage of new and traditional media formats. The teacher uses digital technology and communication, knows the fundamentals of digital technology, uses media to express his ideas through various forms of media.

Defining the sociocultural context of media content. The teacher demonstrates knowledge and understanding of the processes of creation of media content in certain social and cultural contexts, and critically evaluates media content.

Promotion of media and information literacy among students and necessary changes' management. The teacher applies knowledge and skills to introduce media and information literacy into the education process of the school, understands how students interpret and use the media, understands and applies a wide range of practical tasks to develop students' media skills and information literacy.

The curriculum enables teachers not only to become media and information literate, but also to learn and develop education strategies and learning approaches. Teachers learn the difference between media learning and theaching through the media; between media and 
information text strategies for teaching different topics and disciplines; and strategies, which can be used to study media and information texts themselves, how they are created, their ideas and content, and how they can be used by audiences (Wilson, 2011).

The ideas and approaches proposed in the Program offer an opportunity to study the theory and practice of introducing media and information literacy into pedagogical education. The aim of the Program is to support teachers in acquiring competence in media and information literacy in order to develop and implement an appropriate curriculum for secondary schools (although it is certainly not limited to this level).

The Program is conceptualized around three broad components of media and information literacy: text creation, text, audience (The Media and Information Literacy..., 2021).

Text creation. This component explores how a media or information text is created and generated, taking into account such aspects as ownership and governance, political and economic contexts, and individual use of technology. Key questions for students: How is a media or information text created? What are the key design elements or technical components used to create it? What is the role of regulation, ownership and distribution? How do these factors influence the information we get? Can people create their own unique text by analogy?

Text. This component examines information, messages and their meanings, and how meaning is formed by reporting on specific individuals, groups or aspects. Key questions: What message or plot is being transmitted? How do we know this? What kind of information do we get about specific people or problems? How is this information given to us and why?

Audience. This component includes ways of identifying the audience to which the media text is intended, the possible reactions of that audience and the strategies used to interpret the text. The key questions: Who is the target of the text? How can we define this? How does the audience react to the text? What causes this reaction?

The Program contains eleven modules that highlight key themes and issues of contemporary media. The modules can be adapted and extended if necessary. The strategies and activities that engage the learner in content analysis and production (or content creation) have been developed for each module. The pedagogical techniques such as textual analysis, modelling, case studies, media creation are presented and considered within the course modules. They also contain research and problem-oriented training strategies.

Each module is based on a specific theme and/or type of media. A thematic approach to media and information literacy education involves views how information on the same topic is presented in different media and considers the advantages and disadvantages of each as a source of information. A media-specific approach requires careful analysis of this type and how the media presents and transforms information (Wilson, 2011). The Program recognizes the importance of analysing both the text (source of information) and the broader context of this source (Prykhodkina, 2020).

Modules of the Curriculum can be integrated into existing courses or combined to create a separate media and information literacy course. List key aspects of the four modules: citizenship, freedom of speech and information, access to information and lifelong learning; understanding news: media and information ethics; information and media representation (television, film, popular music and print media); languages - codes and designations - media and information literacy; advertising; new and traditional media; Internet: opportunities and challenges; information literacy and library skills; audience; media, technology and Global Village; communication and learning (core module) (Media and information literacy curriculum..., 2014).

In our opinion "Curriculum on media and information literacy" is a valuable resource for any teacher interested in media and information literacy. It establishes common boundaries and terminology for further study of this area. In addition the Program provides opportunities 
for curriculum developers, classroom teachers and media professionals to collaborate in the creation and implementation of media and information literacy programs.

\section{METHODOLOGY}

In order to identify the features of teacher training for media education for students in developed English-speaking countries, we have analysed the official websites of leading universities in Australia, Canada, the United Kingdom and the United States of America according to the following criteria: 1) the university has the education college or a faculty; 2) additional specializations (minors), education programmes in media, media literacy, certificate programs; 3) selective, standard teaching of medical literacy in teacher training programs for secondary schools; 4 ) holding of summer and winter schools for media education.

\section{MAIN RESULTS}

There are three teacher training models in the Australian teacher training system.

1. Parallel - involves two specializations of the same education level: Bachelor of Education / Bachelor of Arts or Bachelor of Education / Bachelor of Science.

2. Consistent - intended for students who already have a bachelor's degree in science or arts, but who also wish to receive a pedagogical education.

3. Training model for the teachers of Pre-school and primary education institution.

In Australia every student who is a future teacher must be a specialist in at least two fields of study, as the Australian Government considers it economically unsustainable to train secondary school teachers in one specialty.

In the first three years, the faculties of the arts or sciences provide students with training in the specializations that the future teacher will teach in the school. Further students continue their studies for two years in faculties of pedagogy. In the faculties of arts or sciences, students study directly the subject to be taught in the school, while in the faculty of pedagogy students learn how to teach these subjects and the course is also supplemented by subjects in the psychological and pedagogical cycle.

Given the division into faculties it should be noted that the Bachelor of Education, Science or Arts course is not divided into two parts, but is an integrated unit, since pedagogical subjects are part of the curriculum throughout the years of study and specialization subjects are also offered at the end of the course.

The University of Sydney which is ranked $22^{\text {nd }}$ offers the following teacher training courses: Bachelor of Science/Bachelor of Secondary Education (specialization: Mathematics); Bachelor of Science/Bachelor of Secondary Education (specialization: Biology, Chemistry, Physics, Geology and Geophysics); Bachelor of Arts/Bachelor of Secondary Education (specialization: in ancient history, modern history, Arabic, Chinese, French, German, Italian, Japanese, Korean, modern Greek, Spanish, Indonesian, Hebrew and Literature, Latin, economics, music and drama); Bachelor of Secondary Education (specialization: Physical Education, Health and Rehabilitation) (Undergraduate programs, 2021).

At the Faculty of Arts and Social Sciences teachers of Department of Media and Communication teach disciplines for students-future bachelors of secondary education, namely:

- Media and Communications. This subject aims to teach students about the media system and how people use the media and its consequences; develop critical thinking skills, media communication, media writing, digital, radio and video content;

- Media Practice aims to develop students' skills in media content creation (writing 
texts for media, online journalism), social media communication, safe media behaviour (The University of Sydney, 2021).

At The University of Adelaide in the Faculty of Arts teacher training based on the double degree program: Bachelor of Media with Bachelor of Arts (BMedia BA) (The University of Adelaide, 2021). The education program of the Bachelor of Media contains the following courses in media: "Key Concepts in Media" (MDIA 1002), "Digital Platforms" (MDIA 1007), "Screen and Sound Industries" (MDIA 1015), "Superheroes: Cinema and Comics" (MDIA 1016), "3D Imaging” (MDIA 1017), "From Storytelling to Data Mining” (MDIA 1018), "Image and Brand" (MDIA 1019), "Media Policy and Media Law" (MDIA 2301), "Media" (MDIA 2302), "Approaches to Media" (MDIA 2306), "Digital Storytelling" (MDIA 2336), "Asian Film Studies»"(MDIA 3313), "Long-form Journalism" (MDIA 3333), "Advanced Digital Promotion" (MDIA 3341), "Media Research Project" (MDIA 3332), "Surveillance and Big Data" (MDIA 3307), "Popular Media: Text, Audience, Industry” (MDIA 3331).

This academic program on media is offered to future teachers as a minor. The faculty also has a rather large list of media closed elective courses.

The University of Adelaide offers Undergraduate Certificates in media for 6 months of full-time or 12 months of part-time study.

- Digital Futures (The University of Adelaide, 2021). The program aims at educating students to understand the role and social influence of media technology in everyday life; research and analysis of media culture in a global context; critical interpretation of professional, moral and cultural policies in media communication.

- Education Media (The University of Adelaide, 2021). The program is aimed to teach students to understand the role and use of media technology in the education process of secondary schools; designing, creating and managing digital education resources; providing a critical interpretation of professional, moral and cultural policies in media communication.

At the School of Education (The University of Newcastle, 2021) at the University of Newcastle, where bachelors and masters of education are trained it is compulsory to study:

- Media Arts Learning in Primary School: An Integrated Approach - EDUC4810 (The University of Newcastle, 2021). The course has 10 credits. The course's task is to create a critical competence among students (awareness of the media texts influence on the psyche and world view), to teach the language of the media through understanding the laws of the media environment and creating their own media texts, to teach to interpret and present their own media in different forms, to form media culture of the network community. The result of mastering the discipline is mastering the skills of analysis, interpretation, creation and evaluation of the media.

- Multiliteracies - EDUC2151 (The University of Newcastle, 2021). The course has 10 credits. It aims to develop students' skills in the use of innovative learning technologies, digital, visual media, critical thinking, media and information literacy.

In Canada, media education courses are taught in almost all Canadian universities. Almost every province in Canada has a Media Education Association that organizes academic conferences, publishes media education periosicals (newspapers, magazines), publishes teaching materials for teachers, etc.

To become a qualified teacher in the United Kingdom a bachelor's degree is required. It is taught in colleges, institutes and universities. In England, Wales and Ireland, it is continuing for three years and for four years in Scotland. After graduation a student can work as a teacher in the primary school and rarely in the secondary school. In England, Wales and Ireland master's degree study is continuing for one year and for two years in Scotland.

According to the Oxford concept the training of future teachers should involve critical research, improvement and experimentation with ideas from different sources, covering on 
the one hand the knowledge and skills of experienced teachers, examples of pedagogical work; on the other hand it is a variety of theoretical and research literature, i.e. practical theory (Pukhovska, 2000).

Teachers are trained in leading higher education institutions in the United Kingdom.

Manchester Metropolitan University (MMU) is a public university located in Manchester, England. The university is the fifth largest university in the United Kingdom. The University of Manchester trains teachers for the various levels of secondary education. The Bachelor's degree program is continuing for three years. After analyzing the teacher training curriculum, we found a compulsory module "Critical Thinking" (Manchester Metropolitan University, 2021), containing specific topics on media literacy. In addition students are offered three-year bachelor programs: Digital Media and Communications BA, Film and Media Studies BA, etc.

University of Leeds (University of Leeds, 2021) is one of the largest education institutions in the United Kingdom which is ranked 49th in pedagogy in the world ranking of universities QS World Uneversity. The university offers three-year undergraduate programs ("Digital Media BA", "Communication and Media, BA", "Cultural and Media Studies, BA" etc.) and one-year master's programs "New Media, MA", "Communication and Media, MA", "Society, Culture and Media, MA" etc.

Institute of Education (IOE) (Institute of Education University..., 2021) is an institution at the University College London (UCL). IOE takes 1 place in the world rating of QS World Uneversity. It is the largest education research authorities in the United Kingdom. The Institute has the largest choice of post-graduate education programs in the United Kingdom. For future teachers the institute offers a three-year bachelor program on media (Media BA). Students study modules on research, analysis and creation of different types of media. Let us look at some of them.

- Media globalization which aims to create knowledge, skills in media operation in the context of globalization, which define the formation of competencies and ensure achievement of the planned results of the education program development.

- Filmmaking is aimed to form skills of film-censers creation, storyboards, shooting (camera movement, angle, distance, frame), director, sound recording, editing (picture, sound, transitions), etc.

- Objects of Media History. Its purpose is to form basic ideas about media development. The course provides an overview of the main technological age in media development. The main attention is paid to the media institutes' development. The course is created to study the role played by the media in the formation of national identities, the history of censorship, key theoretical approaches to the study of media and communications.

- Analysing Media Texts introduces students to the specifics, basic units, categories of modern media texts and the mechanisms of their construction; typology of media texts and basic genre varieties; basic styles of mass communication. The aim of the course is to create students' skills in analyzing informative and verbal peculiarities of media texts in the context of a linguistic picture of the world, correct interpretation of non-verbal and verbal means of creating media texts. The course offers students the opportunity to develop their discussion and writing skills and provides a basis for further modules.

- Designed for VR/AR is designed to teach students the design process for augmented and virtual reality applications.

- Media Literacy. In the framework of which the issues of history, theory and methodology of media literacy, media education concepts, practical experience of conducting media education courses for students and students are considering.

University of Glasgow (University of Glasgow, 2021) is the largest higher education institution in Scotland. It ranks 90th in pedagogy in the world ranking of universities QS 
World Uneversity. The university offers master's programs in media: The Media, Culture \& Society MSc, Media, Communications \& International Journalism MSc, Children's Literature, Media \& Culture, etc.

The nature of the education process requires teachers to continuously improve their skills, constantly enrich their knowledge and reflect on new phenomena that occur in the daily life of the school and in the surrounding world. The incentive for further training is the dependence of wages on the level of education. In developed English-speaking countries there is a system of incentives to improve professional skills. For example, in Canada a teacher with a Master's degree will have a higher grade and therefore higher pay. The Teachers' Federation and other agencies offer workshops, short courses, summer universities and professional conferences.

United States of America. Higher education in the United States can be divided into universities (4-5 years), pedagogical colleges (4-5 years), Liberal Arts colleges or humanities colleges (4 years). There are both State and private education institution. Among the most prominent universities providing teaching personnel are Ball State University (Indiana), Northern Illinois University (Illinois), University of Michigan (Michigan), University of Pennsylvania (Philadelphia). The majority of prospective teachers are studying for four years of schooling (70 per cent), less than a third - for five years and others - for two years (Barnes, 1994).

University teacher training includes a subject specialization and a course in vocational education. However, the content of the curricula and programs of individual subjects as well as the sequencing of their study, vary considerably from one institution to another.

Pedagogical colleges provide for vocational, education and general education training and specialization throughout the training period. In the final semester, time has been set aside for elective courses (Zeichner, 2020).

The humanities colleges which are attended not only by prospective teachers but also by other professionals have a different system of teacher training. The first two years together with all other students receive general education training. A small part of the second and almost all of the third year is subject-matter specialization, and in the third and fourth years pedagogical training and courses of choice.

The United States is a leader in media education. The information analyzed by us in such publications as "Media Matters" (Media Matters for America, 2021), "Education Leadership" (Educational Leadership, 2021) and "The New York Times" (The New York Times, 2021) etc., analysis of education standards and curiculums presented in paragraph 4.1 confirms the importance of media education in the United States. In the beginning of 1990 American researcher K. Tyner noted that "there is a great need to train teachers to teach media literacy" (Tyner, 1992). In her opinion, future teachers need to know how to create web pages or what to choose, how to evaluate learning software, who owns most media, how violence in television affects children etc. Media technologies should be as tools; teachers should ask questions and make policy decisions.

E. Thoman noted that «there is the need for more formal professional growth of teachers and the development of a curriculum on media literacy in pedagogical higher education institutions» (Thoman, 1999). He believes that media literacy should be integrated into all teacher education programs.

According to G. Golovchenko the teachers' training for integration and teaching of selected media literacy subjects in the United States is under way "within the framework of formal education, when prospective teachers receive the first and second levels of higher education; within the framework of non-formal education, when practical teachers acquire the media skills they need through various education and scientific activities, organized by the school administration, professional public associations, which is a manifestation of their professional 
growth; within the framework of information education, working on self-development and self-improvement of their professional skills" (Holovchenko, 2020).

We have reviewed education programs for the teachers' training at major universities in the United States. We note that all institutions offer selective courses in media literacy and offer additional education programs in media research. Some universities offer master's programs in media education.

The Appalachian State University is a state institution owned by the University of North Carolina. The university includes The Reich College of Education (The Reich College of Education..., 2021) where future secondary school teachers study. The list of selected courses of students' choice contains Media Literacy, Media Studies, etc.

The university offers a master's degree program in media education "Educational Media" (Educational Media, 2021). The additional specialization "Media Studies Minor" (Appalachian State University, 2021) for 16 credits was introduced. The curriculum includes compulsory (6 credits) and selective ( 9 credits) disciplines. Compulsory disciplines include:

- Introduction to Sight and Sound - CI 4810 - 3 credits. The purpose of the course is to introduce with the history, development and transformation of audio and visual communication; types of modern audio and visual media (economic and social prerequisites, technical discoveries, traditions of visual culture, human need for information and creativity); stages of formation and specific peculiarities of "language" audio and visual communication with media platforms; features of audio and visual communication in 20th century and Interactive Digital Environment in 21st century.

- CI 4830 - Media Literacy - 3 credits. The course acquaints students with key concepts and principles in the field of media literacy, features of creation of advertising, TV programs, news, influence of media on person, creation and distribution of media texts.

Subjects of choice of the student:

- Advanced Video Production - CI 4552 - 3 credits. The aim of the course is to develop students' skills in the creation of a professional product (video, broadcast, music clip, and documentary film), understanding video production technology, basic stage skills, storyboards, technical aspects of video creation, corrections and sound recordings, basic editing.

- Photography and Digital Imaging - CI 4740 - 3 credits. The course introduces students to the theoretical and practical foundations of digital photography, the digital camera design and its main control nodes, the principles of digital colour imaging and processing, digital image software (for creation of personal copyright, slideshow and photo gallery, electronic photo album, calendar, collage) etc.

Such universities as Appalachian State University, Columbia University, Ithaca College, Brooklyn College, New York University, University of Texas at Austin, University of Rhode Island and University of Maryland offer courses and summer institutes in media literacy for teachers and graduate students. The Brigham Young University offers postgraduate studies in media education for in-service teachers. The teacher training program of the Higher School of Education and Information Research requires that all new teachers complete the four-part course "Critical Media Literacy" (Critical Media Literacy, 2021).

In addition to university education, training and further training, media literacy is offered to teachers by national media education associations. Their main activities in this context are:

- teacher training in media education;

- exchange of pedagogical experience and strengthening of links between scientists and media practitioners;

- resource, methodological and professional support for teachers (development of necessary manuals and practical materials from media education for teachers in accordance with the school curriculum, etc.); 
- provision of film library for media education practitioners;

- holding conferences, courses, seminars, master classes, media education trainings, etc.

One of the most popular ways to improve the qualifications and self-education of teachers is MOOC - Massive Open Online Courses. This is a new world trend in the education system. MOOC is in the list of " 30 most promising trends in the development of education by 2028" (Institut YuNESKO..., 2021). It opened up new opportunities in distance education, which became especially relevant in 2020 due to the COVID-19 pandemic.

The world's first MOOC was founded in the United States (Coursera, EdX, Udacity, Udemy, Khan Academy) and the United Kingdom (Futurelearn). We analyzed the platforms Futurelearn (Futurelearn, 2021), Coursera Coursera, 2021), EdX (Coursera, 2021) regarding the availability of MOOC for media education, media literacy (see tab. 1). It was noted that the largest Australian, American, Canadian and British universities were actively involved in the creation and distribution of education resources, in particular open courses.

Table 1

\section{Results of the analysis of platforms on the presence of MOOC in media education and media literacy}

\begin{tabular}{|c|c|c|}
\hline № & Course title & Developer \\
\hline 1 & 2 & 3 \\
\hline & \multicolumn{2}{|l|}{$E d X$} \\
\hline 1 & Media LIT: Overcoming Information Overload & Arizona State University \\
\hline 2 & $\begin{array}{l}\text { Instructional Design: Digital Media, New Tools and } \\
\text { Technology }\end{array}$ & University of Maryland Global Campus \\
\hline 3 & Sorting Truth From Fiction: Civic Online Reasoning & Massachusetts Institute of Technology \\
\hline 4 & From Digital Technologies to Social Media & Curtin University \\
\hline 5 & Making Sense of News & University of Hong Kong \\
\hline 6 & Fake News, Facts, and Alternative Facts & The University of Michigan \\
\hline 7 & The Story of Fake News & Davidson College \\
\hline 8 & Critical Thinking: Fundamentals of Good Reasoning & IsraelX \\
\hline 9 & Problem Solving and Critical Thinking Skills & Fullbridge \\
\hline 0 & Introduction to Cybersecurity & University of Washington \\
\hline 1 & $\begin{array}{l}\text { Information Security - Introduction to Information } \\
\text { Security }\end{array}$ & New York University \\
\hline \multirow[t]{2}{*}{2} & Global Media, War, and Technology & The University of Queensland \\
\hline & \multicolumn{2}{|l|}{ Futurelearn } \\
\hline 1 & $\begin{array}{l}\text { Understanding Media: Introduction to Media Literacy } \\
\text { and Representation }\end{array}$ & The University of Newcastle Australia \\
\hline 2 & $\begin{array}{l}\text { Disinformation, Misinformation, and Fake News Teach- } \\
\text { Out }\end{array}$ & University of Michigan \\
\hline 3 & Developing Literacy: A Journey from Still Image to Film & Into Film (UK) \\
\hline
\end{tabular}




\begin{tabular}{|c|l|l|}
\hline 4 & $\begin{array}{l}\text { Filmmaking and Animation Online and in the } \\
\text { Classroom }\end{array}$ & Into Film (UK) \\
\hline 5 & Film Education: A User's Guide & The British Film Institute (BFI) \\
\hline 6 & $\begin{array}{l}\text { Using Film to Teach Literacy Online and in the } \\
\text { Classroom }\end{array}$ & Into Film (UK) \\
\hline 7 & Making Sense of Data in the Media & The University of Sheffield \\
\hline 8 & Respecting Our Differences Online & Samsung \\
\hline 9 & Introduction to Cyber Security & The Open University \\
\hline 1 & $\begin{array}{l}\text { Making Sense of the News: News Literacy Lessons for } \\
\text { Digital Citizens }\end{array}$ & New York University \\
\hline 2 & Ethical Social Media & The University of Sydney \\
\hline 3 & $\begin{array}{l}\text { Transmedia Storytelling: Narrative worlds, emerging } \\
\text { technologies, and global audiences }\end{array}$ & The University of Sydney \\
\hline 4 & History and theory of media & HSE University \\
\hline
\end{tabular}

\section{CONLUSIONS}

From the above, the following conclusions follow. Media literacy is an avenue through which expanded literacies can be included in the nation's schools at all levels. It can serve to enliven and to connect teacher education courses, from methods courses and educational psychology to founda- tions courses and student teaching. Media literacy promotes critical thinking, reflection on social issues, understanding of subject areas and children, and teacher professionalism. Now many Canadian, British, Australian, American colleges and universities train teachers in media education. They are acquainted with the media education theory and practice, modern technologies of media education on the system of «key concepts», possibilities of using digital technologies in the process of media education of students. The National Media Education Associations offer vocational courses and media workshops for teachers. One of the most popular ways to improve the qualification and self-education of teachers is MOOC (Futurelearn, Coursera, EdX).

\section{REFERENCES}

Appalachian State University. (2021). Media Studies Minor. Retrieved 2021 from: http:// bulletin.appstate.edu/preview_program.php?catoid=16\&poid $=6291 \&$ returnto $=850$

Appalachian State University. (2021). Program of Study for the Master of Arts in Educational Media. Retrieved 2021 from: http://bulletin.appstate.edu/preview_program.php?catoid= 19\&poid $=8196 \&$ returnto $=1111$

Avsheniuk, N. M. (2016). Tendentsii profesiinoho rozvytku vchyteliv u rozvynenykh anhlomovnykh krainakh v umovakh hlobalizatsii. Naukovyi visnyk Mukachivskoho derzhavnoho universytetu: Pedahohika ta psykholohiia, 1(7), 15-18.

Barnes, G. (1994). The American University. National Textbook.

Considine, D. (1995). Are we there yet? An update on the media literacy movement. Educational Technology, 35(4), 32-45.

Coursera. (2021). Retrieved 2021 from: https://www.coursera.org 
Critical Media Literacy. (2021). Retrieved 2021 from: https://guides.library.ucla.edu/educ466 Davies, J. (1996). Educating students in a media-saturated culture. Technomic Publishing.

Educational Leadership. (2021). Retrieved 2021 from: https://www.ascd.org

EdX. (2021). URL: https://www.edx.org

European Parliament Resolution of 16 December 2008 on Media Literacy in a Digital World (2008). Retrieved 2021 from: http://www.europarl.europa.eu/sides/getDoc.do?pubRef=-// $\mathrm{EP} / / \mathrm{TEXT}+\mathrm{TA}+\mathrm{P} 6-\mathrm{TA}-2008-0598+0+\mathrm{DOC}+\mathrm{XML}+\mathrm{V} 0 / / \mathrm{EN}$

Futurelearn. (2021). Retrieved 2021 from: https://www.futurelearn.com

Holovchenko, H. (2020). Orhanizatsiia mediapidhotovky pedahohiv e SShA ta Kanadi. Naukovyi visnyk Pivdennoukrainskoho natsionalnoho pedahohichnoho un-tu imeni K. D. Ushynskoho, 2(131), 95-103.

Institut YuNESKO po informatsionnyim tehnologiyam $\mathrm{v}$ obrazovanii. Massovyie otkryityie onlayn-kursyi. (2021). Retrieved 2021 from: http://ru.archive.iite.unesco.org/oer_and_ digital_pedagogy/oer/online_courses/

Institute of Education University of London: Media BA. (2021). Retrieved 2021 from: https:// www.ucl.ac.uk/ioe/courses/undergraduate/media-ba

Institute of Education University of London (n.d.). Retrieved 2021 from:

https://www.ucl.ac.uk/ioe/ Lokshyna, O. I. (2020). Profesiinyi rozvytok pedahohiv: pozytsiia mizhnarodnykh orhanizatsii. Rozvytok profesiinoi maisternosti pedahoha $v$ umovakh novoi sotsiokulturnoi realnosti: zbirnyk materialiv III Mizhnar. nauk.-prakt. konf. (m. Ternopil, 09-10 kvit. 2020 r.), 217-220.

Manchester Metropolitan University. (2021). Primary Education with QTS: course information. Retrieved 2021 from: https://www.mmu.ac.uk/study/undergraduate/course/ba-primaryeducation-with-qts/

Media and information literacy curriculum for teachers. (2014). Retrieved 2021 from: https:// unesdoc.unesco.org/ark:/48223/pf0000192971_jpn

Media Matters for America. (2021). Retrieved 2021 from: https://www.mediamatters.org/ search?search $=$ media+education

Prykhodkina, N. O. (2020). Navchalna prohrama z media- ta informatsiinoi hramotnosti YuNESKO: kontseptualni osnovy. Pedahohichni nauky: teoriia, istoriia, innovatsiini tekhnolohii, 1(95), 94-103.

Pukhovska, L. P. (2000). Suchasni doslidzhennia v haluzi pedahohichnoi osvity u krainakh zakhidnoi Yevropy (pp. 565-589). Neperervna profesiina osvita: problemy, poshuky, perspektyvy: monohrafia. Vydavnytstvo «Vipol».

The Media and Information Literacy Curriculum for teachers. (2021). Retrieved 2021 from: https://unesdoc.unesco.org/ark:/48223/pf0000192971

The New York Times. (2021). Retrieved 2021 from: https://www.nytimes.com/ search?query=media+education

The Reich College of Education. Programs of Study. (2021). Retrieved 2021 from: http://bulletin. appstate.edu/content.php?catoid $=16 \&$ navoid $=857$

The University of Adelaide. (2021). Bachelor of Media with Bachelor of Arts (BMedia BA). Retrieved 2021 from: https://calendar.adelaide.edu.au/aprcw/2021/bmeba_bmediabart

The University of Adelaide. (2021). Undergraduate Certificate in Digital Futures. Retrieved 2021 from: https://www.adelaide.edu.au/degree-finder/ucdf_ucdigfutr.html

The University of Adelaide (2021). Undergraduate Certificate in Educational Media. Retrieved 2021 from: https://www.adelaide.edu.au/degree-finder/ucem_uceducmed.html\#df-accfurther_info_parent

The University of Newcastle. (2021). Course Handbook: Media Arts Learning in Primary 
School: An Integrated Approach (EDUC4810). Retrieved 2021 from: https://www. newcastle.edu.au/course/EDUC4810

The University of Newcastle. (2021). Course Handbook: Multiliteracies (EDUC2151). Retrieved 2021 from: https://www.newcastle.edu.au/course/EDUC2151

The University of Newcastle. (2021). School of Education. Retrieved 2021 from: https://www. newcastle.edu.au/school/education

The University of Sydney. (2021). Department of Media and Communications. Retrieved 2021 from: https://www.sydney.edu.au/arts/schools/school-of-literature-art-and-media/ department-of-media-and-communications.html

Thoman, E. (1999). Skills and strategies for media education. Educational Leadership, 56(5), 50-54.

Topuzov, O., Kalinina, L. (2017). Orhanizatsiini mekhanizmy upravlinnia zakladamy osvity: metodolohii ta teoretychni zasady [Organizational mechanisms of management of educational institutions: methodologies and theoretical principles]. Ukrainskyi pedahohichnyi zhurnal, 4, 34-44.

Tyner, K. (1992). The tale of the elephant: Media education in the United States (pp.170-176). In C. Bazalgette, E. Bevort, Savion J. New directions: Media education worldwide. London, UK: British Film Institute.

Undergraduate programs. (2021). Retrieved 2021 from: http://sydney.edu.au/education_social_ work/future_students/undergraduate/index.shtml

University of Glasgow. (2021). Retrieved 2021 from: https://www.gla.ac.uk

University of Leeds. (2021). Retrieved 2021 from: https://www.leeds.ac.uk

Wilson, C. (2011). Media and Information Literacy: Pedagogy and Possibilities. http://unesdoc. unesco.org/images/0019/001929/192971e.pdf

Yakymchuk, I. (2019). Formuvannia mediaosvitnikh kompetentnostei u vykladachiv koledzhu: teoretychnyi aspekt. Nova pedahohichna dumka, 4(100), 69-73.

Zeichner, K. (2020). Preparing Teachers as Democratic Professionals. Action in teacher education. https://www.researchgate.net/publication/338060266_Preparing_Teachers_ as_Democratic_Professionals 